\title{
COVID-19 Pandemisi Döneminde Aşı Reddinin Değerlendirilmesi
}

\author{
Yasin YILDIZ 國 ${ }^{1}$, Tahsin Gökhan TELATAR [0 $^{2}$, Mehmet Halit BAYKAL ${ }^{3}{ }^{3}$, \\ Burcu AYKANAT YURTSEVER [i] $^{3}$, İlknur Esen YILDIZ ${ }^{4}$
}

ÖZ

Amaç: Aşılar, tıbbın insanlığa sağladığı en büyük başarılar arasında olup bugüne kadar milyonlarca kişinin yaşamını kurtarmıştır. Ülkemizde 2017 yılında 23 binden fazla aile aşı reddi talebinde bulunmuştur. Geçmişte salgın hastalıkların yıkıcı etkilerinin pek çok sosyal, coğrafi, ekonomik, kültürel etkilere yol açtığı gözlenmiştir. Bu çalışmada amacımız; COVID-19 pandemisi sırasında Türkiye'de normalleşme sürecinin başlaması sonrasında, geçmişte çocuklarına aşı yaptırmayan ebeveynler ile görüşerek aşı reddi oranlarında bir değişiklik olup olmadığını değerlendirmektir.

Gereç ve Yöntemler: Kesitsel tipteki bu araştırmada aşı reddinde bulunan aileler telefon ile aranarak onayları alındıktan sonra anket çalışması gerçekleştirilmiştir. Görüşmeler, ülkemizde "normalleşme sürecinin” başlangıcı olan Haziran 2020 sonrasında gerçekleştirilmiş, ailelerin aşı reddine ilişkin görüşlerinin COVID-19 pandemisinden etkilenip etkilenmediği araştırılmıştır.

Bulgular: Aşı reddinde bulunan 82 aile çalışmaya katılmayı kabul etmiş ve anket gerçekleştirilmiştir. Hepatit A aşısı ret oranının $(\% 6,5)$ diğer aşılara göre yüksek, Hepatit B aşı1sı ret oranının $(\% 2,1)$ ise diğer aşılara göre düşük olduğu belirlenmiştir. Aşı reddi için en sık sebep "içeriğine güvenmeme" (\%43) olarak gözlenmiştir. Ailelerin tamamı COVID19 pandemisi kontrol önlemleri kapsamında normalleşme sürecine geçilmesi sonrasında da çocuklarına aşı yaptırmayı düşünmediklerini belirtmiştir. Çocuklarına aşı yaptırmayan ebeveynlere "COVID-19 aşısı olsa kendinize yaptırır misınız" sorusu sorulduğunda \%35,7'si olumlu yanıt vermişlerdir.

Sonuç: Çalışmamızda COVID-19 pandemisi için ülkemizde normalleşme sürecine geçilmesi sonrasında ailelerin çocuklarına aşı yaptırma konusunda fikirlerinin değişmediği gözlenmiştir. Aşıların bireysel ve toplumsal faydaları düşünüldüğünde aşı ret oranlarını azaltmaya yönelik çalışmaların önemi ortaya çıkmaktadır.

Anahtar Kelimeler: Aşı karşıtlı̆̆ı; aşı reddi; COVID-19.

\section{Evaluating Vaccine Rejection during COVID-19 Pandemic}

\begin{abstract}
Aim: Vaccines are one of the most tremendous medical success in human history and have saved millions of people until this day. There are more than 23 thousand families who had rejected vaccines in our country in 2017. Outbreaks caused numerous social, geographic, economic, and cultural devastations in the past. This study aims to reveal the change in the ratio of people who refused vaccines after the COVID-19 pandemic.

Material and Methods: This cross-sectional study was conducted via phone interviews with families who rejected vaccines by calling the people who refused to use vaccines after they agreed to join the study. The talks have been made after June 2020, which is also the starting of "normalization process" in our country. It is researched whether the patients' relatives' decisions have been changed during COVID-19..

Results: 82 families who refuse to vaccine their children accepted to join the study. Refusing rate for Hepatitis A $(6.5 \%)$ vaccine was higher among other vaccines, and refusing rate for Hepatitis B $(2.1 \%)$ vaccine was lower among all vaccines. Of the reasons for refusing vaccines, "Not trusting the substance" (43\%) was higher than other causes. When it is asked parents, who refused to vaccines for their children "Do you use for yourself if a vaccine for a COVID-19 invented?" $37.7 \%$ of the participant gave an affirmative answer.
\end{abstract}

\footnotetext{
1 Recep Tayyip Erdoğan Üniversitesi, Tıp Fakültesi, Çocuk Sağlığı ve Hastalıkları Anabilim Dalı, Rize, Türkiye

2 Recep Tayyip Erdoğan Üniversitesi, Tıp Fakültesi, Halk Sağlığı Anabilim Dalı, Rize, Türkiye

3 Rize İI Sağlık Müdürlüğü, Halk Sağlığı Hizmetleri Başkanlığı, Rize, Türkiye

4 Recep Tayyip Erdoğan Üniversitesi, Tıp Fakültesi, Enfeksiyon Hastalıkları ve Klinik Mikrobiyoloji Anabilim Dalı, Rize, Türkiye

Sorumlu Yazar / Corresponding Author: Tahsin Gökhan TELATAR, e-mail: gokhantelatar@gmail.com
} 
Conclusion: At the end of our study, we concluded that the parents' thoughts about vaccines for their children have not changed after the pandemic of COVID-19. Taking direct, indirect, and protective effects of vaccines into consideration on individuals, the importance of studies about decreasing the refusal of vaccines becomes significant.

Keywords: Vaccine opposition; vaccine rejection; COVID-19.

\section{GíRIS}

Aşılar, tıp biliminin insanlığa sağladığı en büyük başarılar arasında olup The Atlantic dergisinin seçkin tarihçilerle yaptığı ankette, "tekerleğin icadından bu yana en büyük buluşlar" listesinde sekizinci sırada, National Geographic' e göre ise "dünyayı değiştiren on buluş" arasında beşinci sırada yer almıştır $(1,2)$. Dünya Sağlık Örgütü (DSÖ) aşıların, "sağlık verilerini iyileştirmek için en başarılı ve uygun maliyetli müdahalelerden biri" olduğunu savunmaktadır (3). 1963 yılında, kızamık aşısı kullanıma sunulduğunda, yılda tahmini 2,6 milyon ölüm gerçekleşirken aşılama kampanyaları sonucunda 2018'de yaklaşık 142 bin ölüme neden olmuştur (4). Benzer şekilde 1980'lerin sonunda, özellikle düşük ve orta gelirli ülkelerde, yılda yaklaşık 350 bin çocuk felci vakası görülürken bağışıklama programı sonrasında 2018'de sadece 33 çocuk felci vakası gözlenmiştir (5). DSÖ' e göre aşıların her yıl toplamda 2-6 milyon hayat kurtardığı tahmin edilmekte ve Birleşmiş Milletler Çocuklara Yardım Fonu (UNICEF) raporuna göre ise "aşılar sayesinde 2000 yılından bu yana 50 milyon çocuğun yaşamı kurtarılmıştır” (6-8).

Aşılama programlarının optimum etkinliği gösterebilmeleri için yüksek uygulama oranlarına sahip olması gerekmektedir. Türkiye Halk Sağlığı Kurumu sağlık istatistiklerine göre 2015 yılında \%97 olan DaBT3 ve KKK aşılama oranının 2016 yılında \%98 olduğu bildirilmiştir (9). Fakat aşıların yan etkileri ve ailelerin endişeleri başta olmak üzere birçok neden aşı karşıtlığına yol açabilmektedir. Aşı karşıtlığı; aşı kararsızlığ1, aş1 tereddüdü ve aşı reddi gibi kavramları içermektedir. DSÖ ve UNICEF'e göre aşı tereddüdü; aşıyı kabullenmekte gecikme veya aşıya ulaşılmış olmasına rağmen reddetme durumu olup, bir ya da daha fazla aşı için söz konusudur. Aşı reddi ise tüm aşıları reddetme, iradesi ile yaptırmama durumu olarak tanımlanmıştır $(10,11)$. Henüz yüksek oranlarda olmasa da Türkiye'de benzer bir eğilim gözlenmekte ve aşı reddi hem hizmet sunumunda hem de zaman zaman kamuoyunda karşılaşılan bir konu haline gelmektedir. Ülkemizde, 2015 y1lında 5091 olan aşıyı reddeden aile sayısı; 2016 yılında 12 binden fazla, 2017 yılında ise 23 binden fazla sayıya ulaşmıştır (12).

Afetler, salgın hastalıklar gibi nüfusun büyük çoğunluğunu etkileyen sorunlar insanlar üzerinde derin izler bırakmaktadır. Geçmişte salgın hastalıkların yıkıcı etkileri pek çok sosyal, coğrafi, ekonomik, kültürel etkilere yol açtığı gözlenmiştir $(13,14)$. Çin'de 31 Aralık 2019 tarihinde ortaya çıkan, Yeni Korona Virüs Hastalığ (COVID-19) olarak adlandırılan ve tüm dünyada 215 ülkeye yayilan enfeksiyon, 11 Mart 2020 itibariyle DSÖ tarafından "pandemi" olarak sınıflandırılmıştır $(15,16)$. COVID-19 enfeksiyonun kesin tedavisi şu an için bilinmemekle birlikte birçok ülkede aşı ve ilaç üretimi çalışmaları başlamıştır. Bu durum hemen her gün medya aracılığıyla dile getirilmekte ve aşı tedavisi COVID-19 tedavisinde büyük umutlarla beklenmektedir (17). COVID-19 pandemisinin halkın sağlık sistemine bakış açısını etkileyip ailelerin aşı reddi konusunda fikirlerini değiştirmesi muhtemel olup konu ile ilgili bilimsel araştırmalara ihtiyaç vardır.

$\mathrm{Bu}$ nedenle çalışmada amacımız; COVID-19 pandemisi döneminde Rize ilinde geçmişte aşı reddi nedeniyle çocuklarına aşı yaptırmayan ebeveynlerin bu konudaki görüşlerini öğrenebilmektir. Böylece pandeminin, aşı reddi oranlarında bir değişikliğe neden olup olmadığını değerlendirmek mümkün olacaktır.

\section{GEREÇ VE YÖNTEMLER}

Çalışma Tasarımı: Çalışmamız retrospektif kesitsel bir çalışma olup Rize İl Sağlık Müdürlüğü desteği ile Recep Tayyip Erdoğan Üniversitesi Tıp Fakültesi Çocuk Sağlığı ve Hastalıkları ve Halk Sağlığı Anabilim Dalı'nda gerçekleştirilmiştir. Aralık 2019-Nisan 2020 tarihleri arasında çocuğuna aşı yaptırmayı reddeden aileler tespit edilmiş ve telefon ile aranarak onayları alındıktan sonra anket çalışması gerçekleştirilmiştir. Görüşmeler "normalleşme sürecinin" başlangıcı olan Haziran 2020 sonrasında gerçekleştirilmiş olup aşı reddinde bulunan hasta yakınlarının COVID-19 pandemisinden etkilenip etkilenmediği araştırılmıştır.

Çalışmanın evreni; Araştırmanın evrenini Rize ilinde ikamet eden, Sağlık Bakanlığının aşı takvimine göre aşı yapılmaya uygun yaşta çocuğu olan ve Aralık 2019-Nisan 2020 tarihleri arasında çocuğuna bir ya da daha fazla aşı yaptırmayı kabul etmemiş olan toplam 102 aile oluşturmaktadır. Araştırma kapsamında ailelerin tamamına telefonla ulaşılmaya çalışılmış, sonuçta 82 aileye $(\% 80,4)$ ulaşılmıştır. Ulaşılan ailelerin tamamı araştırmaya katılmayı kabul etmiştir. Görüşmeleri tamamı çocukların anneleri ile yapılmıştır.

Veri toplama aracı: Veriler yapılandırılmış bir anket formu aracılığı ile telefon görüşmesi vasıtasıyla toplanmıştır. Veri topluma formu, aşı reddinde bulunan ailede görüşülen kişinin bazı sosyodemografik özellikleri, aşı reddi nedenleri, reddedilen aşı ile ilgili özellikler ve aşı reddine ilişkin tutumlarının değerlendirildiği bölümlerden oluşmaktadır. Veri toplanması sırasında telefon görüşmeleri için İl Sağlık Müdürlüğüne ait kayıtlar resmi izin alınarak kullanılmıştır ve görüşmeler, araştırmacılar arasında da bulunan ìl Sağlık Müdürlügüüde görevli bir uzman hekim aracılığıyla gerçekleştirilmiştir.

\section{İstatistiksel analiz}

Araştırmanın verileri, IBM SPSS 23.0 (Chicago, USA) yazılımı ile değerlendirilmiştir. Verilerin değerlendirilmesinde tanımlayıcı istatistikler (yüzde, frekans, ortalama/ standart sapma) kullanılmıştır. Araştırmada bir örneklem belirlenmemiş, evrenin tamamına ulaşılmaya çalışılmıştır.

Etik konular: Araştırma için TC Sağlık Bakanlığı Sağlık Hizmetleri Genel Müdürlüğü Bilimsel Araştırma Komisyonu (İzin no: 2020-05-29T16_07_04), Rize İl Sağlık Müdürlüğü (İzin no: 64242179-79̄9) ve Recep Tayyip Erdoğan Üniversitesi Tıp Fakültesi Girişimsel Olmayan Etik Kurulu'ndan 01.07.2020 tarih ve 2020/137 sayılı izin alınmıştır. Araştırma için ulaşılan ailelerin 
tamamına önce araştırma hakkında açıklayıcı bilgi varilmiş, daha sonra araştırmaya katılmaya gönüllü olanlar ile görüşme yapılmıştır. Araştırma boyunca Helsinki Deklerasyonu prensiplerine tam olarak uyulmuştur. Toplam 102 aile arasında telefonla ulaşılabilen 82 aileden görüşülen kişilerin tamamı araştırmaya katılmayı kabul etmiştir.
Aş1 reddi talebinde bulunan 102 aileden 82'si $(\% 80,4)$ çalışmaya katılmayı kabul etmiş ve telefon görüşmesi ile anket gerçekleştirilmiştir. Çalışmaya alınan çocukların yaşları ortalama $1,75 \pm 0,79$ yıldır. Çocukların sosyodemografik verileri Tablo 1'de verilmiştir.

\section{BULGULAR}

Tablo 1. Çalışmaya alınan çocukların sosyo-demografik özellikleri

\begin{tabular}{|c|c|c|}
\hline & $\mathbf{n}$ & $\%$ \\
\hline \multicolumn{3}{|c|}{ Yaş (ay) } \\
\hline $0-12$ & 10 & 12,2 \\
\hline 13-24 & 39 & 47,6 \\
\hline $25-36$ & 27 & 32,9 \\
\hline $37-48$ & 6 & 7,3 \\
\hline \multicolumn{3}{|c|}{ Kardeş sayısı } \\
\hline Tek çocuk & 33 & 40,2 \\
\hline 1 kardeş & 29 & 35,4 \\
\hline 2 kardeş & 15 & 18,3 \\
\hline 3 kardeş & 5 & 6,1 \\
\hline
\end{tabular}

Çalışmaya alınan çocuklarda aşı reddi sıklığı birinci doz Hepatit A aşısı $(\% 6,5)$ için diğer aşılardan daha yüksek olarak bulunmuştur. Hepatit B aşısı $(\% 2,1)$ için aşı reddi diğer aşılardan daha düşük sıklıkta gözlenmiştir. Ailelerin \%58,5'i çocuğu için tüm aşıları reddetmiştir. Reddedilen aşılar ile ilgili bilgiler Tablo 2'de verilmiştir.

Tablo 2. Sağlık Bakanlığı takvimine göre reddedilen aşıların dağılımı [n(\%)]*

\begin{tabular}{|l|c|c|c|c|c|c|c|c|c|}
\hline & Doğumda & $\mathbf{1 . ~ a y}$ & $\mathbf{2 .}$ ay & $\mathbf{4 . ~ a y}$ & $\mathbf{6 .}$ ay & $\mathbf{1 2 .}$ ay & 18. ay & 1. sinıf & 8. sinıf \\
\hline Hepatit B & $9(2,1)$ & $16(3,7)$ & & & $16(3,7)$ & & & & \\
\hline BCG & & & $19(4,4)$ & & & & & & \\
\hline DaBT-IPA-Hib & & & $22(5,1)$ & $22(5,1)$ & $24(5,6)$ & & $26(6,1)$ & \\
\hline KPA & & & $19(4,4)$ & $19(4,4)$ & & $22(5,1)$ & & & \\
\hline KKK & & & & & & $22(5,1)$ & & $24(5,6)$ & \\
\hline DaBT-IPA & & & & & & & & $26(6,1)$ & \\
\hline OPA & & & & & $17(4)$ & & $24(5,6)$ & & \\
\hline Td & & & & & & & & & \\
\hline Hepatit A & & & & & & & $28(6,5)$ & $27(6,3)$ & \\
\hline Suçiçeği & & & & & & $23(5,4)$ & & & \\
\hline
\end{tabular}

*Yüzdeler tüm aşılar üzerinden hesaplanmıştır.

DaBT-IPA-Hib: Difteri aselüler, boğmaca, tetanoz, inaktif polio, Hemofilus influenza Tip B (beşli karma aşı)

KPA: Konjuge pnömokok aşısı

KKK: Kızamık, kızamıkçık, kabakulak aşısı

DaBT-IPA: Difteri aselüler, boğmaca, tetanoz, inaktif polio aşısı (dörtlü karma aşı)

OPA: Oral polio așısı

Td: Erişkin tipi difteri - tetanoz aşısı

Aşı reddinde bulunan ailelerin aşı reddi nedenleri araştırıldığında "Aşı içeriğine güvenmeme" (\%43) önermesinin diğer ifadelerden daha sık kullanıldığı gözlenmiştir. Aşı reddi nedenleri Tablo 3 ’te verilmiştir.

Tablo 3. Aș1 reddi nedenleri*

\begin{tabular}{|c|c|c|}
\hline 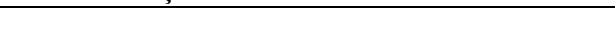 & $\mathbf{n}$ & $\%$ \\
\hline Aşı içeriğine güvenmediği için & 61 & 43,0 \\
\hline Yurtdışı kaynaklı olduğu için & 34 & 23,9 \\
\hline Sosyal medyadan yaptığı inceleme sonucu & 26 & 18,3 \\
\hline Dini yönden uygun görmediği için & 5 & 3,5 \\
\hline Sağlık personelinin yönlendirmemesi sonucu & 3 & 2,1 \\
\hline Diğer & 13 & 9,2 \\
\hline
\end{tabular}

\footnotetext{
* Soruya birden fazla cevap verilmiştir
} 
Aşı reddi üzerinde COVID-19 pandemisinin etkisinin olup olmadığı araştırılmış ve ailelerin çocuklarına aşı yaptırma konusundaki görüşlerinin pandeminin başından araştırmanın yapıldı̆̆ı zamana kadar değişmediği, tamamının halen çocuklarına aşı yaptırmama kararını devam ettirdikleri gözlenmiştir.

Tablo 4. Așı yaptırma durumu ile ilgili özellikler

\begin{tabular}{|c|c|c|}
\hline & $\mathbf{n}$ & $\%$ \\
\hline \multicolumn{3}{|c|}{$\begin{array}{l}\text { Diğer çocuklarında aşı reddi var mı? } \\
\text { (Tek çocuk olmayanlar) }\end{array}$} \\
\hline Evet & 22 & 46,8 \\
\hline Hayır & 25 & 53,2 \\
\hline \multicolumn{3}{|c|}{ COVID-19 aşısı olsa kendine yaptırır mı? } \\
\hline Evet & 29 & 35,4 \\
\hline Hayır & 53 & 64,6 \\
\hline \multicolumn{3}{|c|}{$\begin{array}{l}\text { COVID-19 sonrası çocuğuna aşı yaptırma } \\
\text { konusunda fikri değişti mi? }\end{array}$} \\
\hline Evet & - & - \\
\hline Hayır & 82 & 100,0 \\
\hline
\end{tabular}

\section{TARTIŞMA}

Enfeksiyon hastalıklarını ve komplikasyonlarını önleyerek milyonlarca çocuğun yaşamını kurtaran/engelli kalmalarını önleyen aşılar, günümüzde bulaşıcı hastalıklarla mücadelede en etkili yöntemlerden biri olarak görülmektedir. Ülkemizde Ulusal Bağışıklama Programı kapsamında 13 farklı aşı yer almakta olup, yapılacak aşıların kapsamı ve takvimi Sağlık Bakanlığı Aşı Danışma Kurulunca belirlenmekte ve sürekli olarak güncellenmektedir (18).

Terminolojik olarak incelendiğinde, eksik aş1; aş1 takviminde belirtilen aralıklara göre yapılması gereken aşıların eksik olma durumu, aşı tereddütü (kararsızlığı); bir ya da daha fazla aşı için aşıyı kabullenmekte gecikme veya aşıya ulaşılmış olmasına rağmen reddetme durumu, aşı reddi; tüm aşıları reddetme iradesi ile yaptırmama durumu olarak tanımlanabilir (18). Çalışmamızda tüm aşıları reddeden ailelerin oranı $\% 58,5$ 'tir. Fakat aşıların tekil olarak ret oranları incelendiğinde, Hepatit A aşısı reddi diğer aşılardan daha sık görülmekte olup yaş ilerledikçe reddedilme oranlarının arttığı gözlenmiştir. Benzer şekilde ülkemizde aşı reddinin Doğu ve Güneydoğu Anadolu Bölgesi'nde diğer bölgelere göre daha fazla olduğu, sıfir yaş grubunda binde üç, okul yaş grubunda yüzde beş civarında olduğu gözlenmiştir. Ayrıca ileri yaşlarda eksik aşılı olma sayısının da daha fazla olduğu bildirilmiştir (18). Çalışmamızda aynı zamanda birden fazla çocuğu olan 47 ailenin 25' inin $(\% 53,2)$ önceki çocuklarında aşı reddinde bulunmadıkları gözlenmiştir. Bu durum, son zamanlarda aşı reddindeki artışın göstergesi olarak dikkat çekici bir örnek olabilir.

Aşıların hem bireysel hem de toplum etkinlikleri olup nüfusun yeterince yüksek bir kısmı aşılandığında, 'toplumsal bağışıklık' (Herd Immunity) meydana gelir ve bir salgın riski önemli ölçüde azalır. Çünkü hastalığın yayılabileceği çok az sayıda aşılanmamış insan vardır. Toplumsal bağışıklığı sağlamak için aşılanması gereken nüfusun oranı, hastalığın ne kadar bulaşıcı olduğuna bağlıdır. Çocuk felci gibi daha az bulaşıcı hastalıkların yayılmasını durdurmak için \%80-85 bağışıklık oranı yeterli iken kızamık için bu oran \%9095' tir (7). Tersi olarak aşılama oranlarının düşmesi hastalığın sıklığının artışı anlamına gelecektir. Ülkemizde aşı karşıtlığının bu şekilde devam etmesi durumunda beş y1l sonra bağışıklama oranının \%80'lere düşebileceği ve böylelikle nadir görülen hastalıkların görülme sıklığının artacağı bildirilmiştir (19). Örnek olarak yalnızca 2019 yılında Amerika Birleşik Devletleri'nde 1.282 doğrulanmış kızamık vakası tespit edilmiştir. Bu durum ülkede 1992 'den beri bildirilen en büyük sayı olup 20 y1l önce verilen kızamık eleme statüsünü kaybetme olasılığın gündeme getirmiştir (20).

Gelişmekte olan ve gelişmiş ülkelerde aşıların yaygınlaştırılmasını engelleyen birçok neden bulunmaktadır. Aşı reddindeki öncelikli neden aşılara karşı ön yargılar ve özellikle gelişmekte olan ülkelerde aşı takvimi dışındaki aşıların maliyetleridir (21). Çocukların aşılanma oranlarının istenilen düzeyde olmamasının nedenleri arasında; aşı maliyetinin yüksek olması, bazı aşıların ulusal aşı programında olmaması, mevcut hastalığın önemli sağlık sorunu olarak görülmemesi, aşının sağlanmasındaki güçlükler, ailelerin ya da sağlık çalışanlarının aşılamayı zamanında yapmaması/ yaptırmaması, sağlık personelinin aşı öncesi ve sonrası yeterli eğitim vermemesi, aşı kartı verilmemesi, aşı günü uygulamaları, bilgi eksikliği, ebeveynlerin aşı içeriğiyle ilgili endişelerinin olması gibi nedenler sayılabilir (21). Bununla birlikte ailedeki çocuk sayıs1, ebeveynlerin eğitim durumları, ebeveynlerin aş1 konusundaki düşünce ve yaklaşımları, ailelerin dini inançları, sosyal güvence varlığı gibi sosyo-demografik özellikler çocukların aşılanma sıklığını etkilediği bilinmektedir (22). Çalışmamızda "içeriğine güvenmeme" ve "aşının yurtdışı kaynaklı olması" önermeleri katılımcilar tarafindan diğer nedenlere göre daha sık belirtilmiştir (\%43 ve \%23,9). Dini kaygılara bağlı aşı reddi oranı düşük iken aşı karşıtı sağlık çalışanlarının yaptıkları açıklamaların da etkili olduğu tespit edilmiştir $(\% 3,5$ ve $\% 2,1)$. 
Aşıların bireysel, toplumsal etkileri dişında çapraz reaksiyonlar sayesinde dolaylı etkileri de mevcuttur. Dolayısıyla aşı reddinde bulunan kişi bu etkilerden de uzak kalacaktır. Hatta aşı reddinin birden fazla aşıyı içermesi ve bu kişilerin birden fazla aşıyı yaptırmamış olmaları nedeniyle olası farklı klinik etkileşimler de engellenecektir. Yapılan kontrollü çalışmalarda BCG aşısının, yapısal olarak benzer tek sarmallı RNA içermesi nedeniyle, farklı virüslerin neden olduğu enfeksiyonların şiddetini azalttığı gösterilmiştir. Hollanda'da yapılan bir çalışmada, BCG aşısının, sağlıklı gönüllülerde sarıhumma aşısının neden olduğu viremiyi $\% 71$ oranında azalttığ1 gözlenmiştir (23). Hindistan gibi tüberkülozun endemik olduğu ülkelerdeki insanlar, BCG aşısının yapılmadığı tüberküloz endemik olmayan ülkelere (Avrupa ve ABD gibi) kıyasla COVID-19 şiddet ve ölüm açısından bir miktar korumaya sahip olduğu görünmektedir. BCG aşısına karşı gelişen bağışıklığın COVID-19 enfeksiyonunu durduramayabileceği, ancak seçici bireyler üzerindeki virülansını azaltabileceği görülmektedir (24). Farklı bir çalışmada, yaşlı yetişkinler ve / veya risk altındaki yetişkinler arasında hali hazırda rutin kullanımda olan hem mevsimsel grip hem de PPV23 (pnömokok) yüksek aşılanma oranlarının, yalnızca hedeflenen hastalıkların yükünü azaltmakla kalmayıp aynı zamanda COVID-19'a bağlı mortalite ve morbidite oranlarını önleme potansiyeline sahip olduğu gösterilmiştir (25). Bulgular henüz yeterli olmasa da aşılar arası etkileşimin COVID-19 kliniği üzerinde pozitif yönde etki edebileceği düşünülebilir. Aşı reddi nedeniyle bu etkileşimin olmayışı farklı riskleri beraberinde getirmektedir.

Gelişen teknoloji sayesinde COVID-19 ile ilgili bilimsel yayınlar veya keşif hızı emsalsiz niteliktedir. COVID-19 salgını ilk kez Aralık 2019'da Çin'in Wuhan kentini vurduğundan beri, bilim adamları SARS-CoV-2'ye karşı koruma sağlamak için yeni aşılar geliştirmek ve test etmek için bir yarış göstermektedir. Benzer şekilde COVID-19 salgını iletişim kanallarında da oldukça geniş yer almakta ve aşı çalışmalarındaki gelişim gün gün takip edilmektedir. $\mathrm{Bu}$ durumun insanların aşılara karşı tutumları üzerinde ne gibi değişiklik meydana getireceği tartışmalıdır. Bir grup bilim adamı aşı gelişim sürecinde acele edilip, yapılması gereken testlerin optimal uygulanmaması ve üretim aşamasının test edilmeden uygulamaya geçişinin halk üzerinde olumsuz tepkilere neden olacağını savunmakta hatta ruhsatlandırma sonrası önemli toksisitelere yol açabilecek bir aşının halk üzerinde ciddi olumsuzluklar oluşturabileceğini belirtmektedir (26). Karşı görüş ise; COVID-19 krizinin, bulaşıcı hastalıklara karşı mücadelede insanların kolektif hafızasını ateşleyebileceği ve aşılara olan güven sorununu çözebileceği yönündedir (26). Arama motorları üzerinden Web tabanlı gerçekleştirilen bir çalışmada 2020'de "koronavirüs" ile pnömokok $(\mathrm{R}=0,89, \mathrm{p}<0,0001)$ ve influenza aşıları $(\mathrm{R}=0,93, \mathrm{p}<0,0001)$ için arama sayıları arasında önemli pozitif korelasyonlar bulunmuştur. Ayrıca influenza ve pnömokok aşılarının aranma sayıları 2015-2019 dönemine kıyasla anlamlı seviyede yüksek tespit edilmiştir (sırasıyla $\mathrm{p}=0,005, \mathrm{p}<0,0001$ ). $\mathrm{Bu}$ sonucun, önümüzdeki sezonda zatürree ve grip aşılarına olan talebin artacağını müjdeleyebileceği ifade edilmiştir. Benzer durumun COVID-19 için de geçerli olabileceği ve küresel olayların, aşıların önemi konusunda halkın algısını değiştirebileceği belirtilmiştir (27). Çalışmamızda "COVID-19 pandemisi ile birlikte çocuğunuza aş1 yaptırma konusunda fikriniz değişti mi” sorusuna tüm katılımcılar olumsuz yanıt vermiştir. Çocuklarına aşı yaptırmayan ebeveynlere "COVID-19 aşısı olsa kendinize yaptırır mısınız" sorusu yöneltilmiş ve \%35,7'si kendilerine yaptıracaklarını belirtmişlerdir. Bu durum farklı basın organlarında çocukların COVID19'dan en az etkilenen grup olduğuna yönelik yayınlardan kaynaklanıyor olabilir, ancak gerçek nedenlerin anlaşılabilmesi için odak grup görüşmeleri gibi yöntemlerle yapılacak ileri araştırmalara gereksinim bulunmaktadir.

\section{Kisıtlılıklar}

Çalışmamız Doğu Karadeniz bölgesinde toplam nüfusu yaklaşık 350 bin olan bir ilde gerçekleştirilmiş olup sadece 2020 yılının verilerini içermektedir. Geçmiş yıllardaki verilerle kıyaslama yaparak değişimi gözleme imkânı bulunamamıştır. Ayrıca "aşı tehiri” tanımına uygun vakalar çalışmada sınıflandırılamamıştır. Çünkü ailelerin COVID-19 döneminde sağlık merkezlerine başvuru oranları azalmış olup salgın sonrası dönemde, halen yaptırmadıkları aşıları ilerleyen süreçte yaptırmaları ihtimal dahilindedir. Dolayısıyla daha geniş çaplı, geçmiş yılların verilerini de içeren, aşı reddi terminolojisindeki diğer tanımları da inceleyen ve yerli aşıya bakış açısını irdeleyen çalışmalara ihtiyaç vardır.

\section{SONUÇ}

Küresel olayların insanlar üzerinde derin etkiler bırakacağ1 bilinmekte fakat COVID-19 pandemisinin aşı karşıtlığ1 konusunda nasıl bir etki göstereceği henüz tahmin edilememektedir. Çalışmamızda pandemi döneminde normalleşme sürecine geçilmesi ile birlikte ailelerin çocuklarına aşı yaptırma konusunda fikirlerinin değişmediği gözlenmiştir. Fakat ilginç şekilde çocuklarına aşı yaptırmayan bu ebeveynler, SARS-CoV2'ye karşı aşı geliştirilse kendilerine yaptıracaklarını belirtmişlerdir.

\section{Öneriler}

Aşı reddi oranları giderek artış göstermekte ve toplumsal bir problem olma yolunda ilerlemektedir. Aşıların kişiler üzerinde hem doğrudan hem de dolaylı etkileri yanı sıra toplum genelindeki koruyucu etkileri düşünüldüğünde, aşı ret oranlarını azaltmaya yönelik çalışmaların önemi ortaya çıkmaktadır. Konu sağlık merkezlerinde, okullarda, haberleşme kanalları gibi sosyal etkileşimin yüksek olduğu zeminlerde gündeme getirilerek aşı reddi oranlarının azaltılması sağlanmalıdır. Ailelerin aşı yaptırmayı reddetmesinin altında yatan gerçek nedenler tespit edilerek nedene özel ve ailelerin çekincelerini giderecek müdahalelere ihtiyaç duyulmaktadır.

Yazarların Katkıları: Fikir/Kavram: Y.Y., T.G.T., M.H.B., B.A.Y., İ.E.Y.; Tasarım: Y.Y., T.G.T., M.H.B., B.A.Y., İ.E.Y.; Veri Toplama ve/veya İşleme: T.G.T., M.H.B., B.A.Y.; Analiz ve/veya Yorum: Y.Y., T.G.T.; Literatür Taraması: Y.Y., T.G.T., İ.E.Y.; Makale Yazımı: Y.Y., İ.E.Y.; Eleştirel İnceleme: Y.Y., T.G.T., M.H.B., B.A.Y., İ.E.Y. 


\section{KAYNAKLAR}

1. Fallows J. Theatlantic.com [Internet]. The 50 greatest breakthroughs since the wheel. [Updated: 2013; Cited: 2020 Apr 3]. Available from: https://www.theatlantic.com/magazine/archive/2013/1 1/innovations-list/309536/.

2. Stone D. Nationalgeographic.com [Internet]. The 10 inventions that changed the world. National Geographic magazine. [Updated: 2017; Cited: 2020 Apr 3]. Available from: https://www.nationalgeographic.com/magazine/2017/ 06/explore-top-ten-innovations/.

3. World Health Organization [Internet]. Strategic Advisory Group of Experts on Immunization, Report of the SAGE working group on vaccine hesitancy. [Updated: 2014; Cited: 2020 May 5]. Available from: https://www.who.int/immunization/policy/position_pa pers/Interim_SAGE_influenza_vaccination_recomme ndations.pdf?ua $=1$.

4. World Health Organization [Internet]. Measles. [Updated: 2019; Cited: 2020 May 11]. Available from: https://www.who.int/csr/don/26-november2019-measles-global_situation/en/.

5. World Health Organization [Internet]. Disease Elimination. [Updated: 2017; Cited: 2020 Apr 18]. Available from: https://www.who.int/immunization/global_vaccine_ac tion_plan/gvap_2017_secretariat_report_poliomyelitis .pdf?ua $=1$.

6. World Health Organization [Internet]. World Bank, State of the world's vaccines and immunization. [Updated: 2019; Cited: 2020 Apr 21]. Available from: https://apps.who.int/iris/bitstream/handle/10665/4416 9/9789241563864_eng.pdf;jsessionid=D3EE93EF6D 5D9E3D3DF2CECB97C2FEAE? sequence $=1$.

7. Kennedy J. Vaccine hesitancy: A growing concern. Pediatric Drugs. 2020; 22(2): 105-11.

8. UNICEF [Internet]. 7,000 newborns die every day, despite steady decrease in under-five mortality, new report says. [Updated: 2017; Cited: 2020 Apr 21]. Available

from: https://www.unicef.org/turkey/en/press-releases/7000newborns-die-every-day-despite-steady-decreaseunder-five-mortality-new-report.

9. Sağlık Bakanlığı [Internet]. Sağlık İstatistikleri Y1llığ1. [Updated: 2016; Cited: 2020 Apr 21]. Available from: https://dosyasb.saglik.gov.tr/Eklenti/13183,sy2016tur kcepdf.pdf?0.

10. Larsona HJ, Jarrett C, Schulz WS, Chaudhuri M, Zhou Y, Dube E, et al. The SAGE Working Group on Vaccine Hesitancy. Measuring vaccine hesitancy: The development of a survey tool. Vaccine. 2015; 33: 4165-75.

11. Kader Ç. Aşı karşıtlığg: Aşı kararsızlığı ve aşı reddi. ESTÜDAM Halk Sağlığı Dergisi. 2019; 4(3): 377-88.

12. Sağlık Bakanlığı, Enfeksiyon Hastalıkları Derneği [Internet]. 3. Ulusal Aşı Çalıştayı, Çalıştay Raporu. [Updated: 2018; Cited: 2020 May 4]. Available from: http://www.solunum.org.tr/TusadData/userfiles/file/3 _UlusalAsiCalistayiRaporu.pdf.
13. Özgür Y. 1847-1848 kolera salgını ve Osmanlı coğrafyasındaki etkileri. Avrasya İncelemeleri Dergisi. 2017; 6(1): 23-55.

14. BBC News [Internet]. Koronavirüs: Tarihin akışını değiştiren beş salgın. [Updated: 2020; Cited: 2020 May 17]. Available from: https://www.bbc.com/turkce/haberler-dunya51970490.

15. Worldometers.info [Internet]. COVID-19 Coronavirus Pandemic. [Updated: 2020; Cited: 2020 May 24]. Available from: https://www.worldometers.info/coronavirus.

16. World Health Organization [Internet]. WHO DirectorGeneral's opening remarks at the media briefing on COVID-19. [Updated: 2020 Mar 11; Cited: 2020 May 17]. Available from: https://www.who.int/dg/speeches/detail/who-directorgeneral-s-opening-remarks-at-the-media-briefing-oncovid-19---11-march-2020

17. Gallagher J. BBC News [Internet]. Coronavirus vaccine: When will we have one? [Updated: 2020; Cited: 2020 May 17]. Available from: https://www.bbc.com/news/health-51665497

18. Üner S, Çelik K, Turan S. Çocuk aşılarında artan kararsılık: Nedenleri farklı aktörlerin deneyiminden anlamak. Ankara: Hipokrat Yayınevi; 2020.

19. Bozkurt HB. An overview of vaccine rejection and review of literature. Kafkas J Med Sci. 2018; 8(1): 716.

20. Patel M, Lee AD, Redd SB, Clemmons NS, McNall RJ, Cohn AC, et al. Increase in measles cases: United States, January 1-April 26, 2019. MMWR Morb Mortal Wkly Rep. 2019; 68(17): 402-4.

21. Gencer MZ, Alıcıoğlu F, Arıca S, Arıca V. 24-72 ay çocukları olan ebeveynlerin sosyo-demografik özellikleri ve rutin aşılar hakkındaki bilgi düzeyleri: Doğu-Batı karşılaştırması. Konuralp Tıp Dergisi. 2015; 7(3): 141-5.

22. Reading R, Surridge H, Adamson R. Infant immunization and family size. Journal Public Health. 2004; 26(4): 369-71.

23. Arts R, Moorlag S, Novakovic B, Li Y, Wang S, Oosting $\mathrm{M}$, et al. BCG vaccination protects against experimental viral infection in humans through the induction of cytokines associated with trained immunity. Cell Host Microbe. 2018; 23(1): 89-100.

24. Mohapatra PR, Mishra B. BCG vaccination policy and protection against COVID-19: Correspondence. Indian Journal of Pediatrics. 2020; 87(9): 772-3.

25. Thindwa D, Quesada MG, Liu Y, Bennett J, Cohen C, Knoll MD, et al. Use of seasonal influenza and pneumococcal polysaccharide vaccines in older adults to reduce COVID-19 mortality. Vaccine. 2020; 38(34): 5398-401.

26. Harrison EA, Wu JW. Vaccine confidence in the time of COVID-19. European Journal of Epidemiology. 2020; 35(4): 325-30.

27. Paguio, JA, Yao JS, Dee EC. Silver lining of COVID19: Heightened global interest in pneumococcal and influenza vaccines, an infodemiology study. Vaccine. 2020; 38(34): 5430-5. 